\title{
Perpetual Strangers: animals and the cosmopolitan right
}

Traditional theories of animal rights are based upon the argument that species membership is a morally arbitrary feature in ethical reasoning. Rather than base moral standing upon common humanity, animal rights theorists have claimed that all sentient creatures, or creatures above a certain level of sentience, belong to the same ethical community, and thus are rights bearers. In this way, animal rights theories appear broadly cosmopolitan in intent. Cosmopolitans meanwhile, hold that all human beings belong to the same ethical community regardless of their other identities or affiliations. At the same time, to be cosmopolitan is also to possess state of mind or to engage with others in a way that is open and accepting of difference. Animal rights theories therefore appear to merely widen the basic cosmopolitan ethical community so that it includes non-human animals, and to be more open in engagement with Others. However, animal rights theories have stopped short of fully embracing cosmopolitanism in two significant ways. First, by focussing on similarities and relationships between humans and other animals as a means of cultivating ethical concern, and second, by demanding that humans and other animals lead rigidly separate lives.

In this paper I draw cosmopolitanism and traditional animal rights theory closer together in order to address problems with each. I argue that an ethic of respect for non-human animals requires us to initially approach them on the basis of difference. Respect for non-human animals demands that we defend those with whom we cannot easily find compassion in our hearts as much as it does for those we find it easy to relate to. I share the view of Martha Nussbaum, that to be 
worthy of the name, global justice must apply across the species. ${ }^{1}$ The cosmopolitan ethic is not only a principle that should guide our encounters with fellow humans, but also with other species. Animal rights theory should therefore be thought of as a cosmopolitan expansion of universal human rights across the species barrier, and, at the same time, this implies that cosmopolitanism should be species blind. Adopting a cosmopolitan approach to animal rights moves us beyond individual duties of non-maleficence towards non-human animals. Cosmopolitanism offers ethical principles that also inform how political communities should interact with non-human animals. Where traditional animal rights approaches have largely concerned themselves with the avoidance of harm by individuals, cosmopolitanism looks to establish conditions for peaceful co-existence between species and political communities. And, where traditional approaches have struggled with positive duties of aid and issues of non-compliance with the duty of non-maleficence, cosmopolitanism provides action-guiding rules in both cases. A cosmopolitan approach to animal rights is not only better suited to the realities of human and non-human co-existence, but also moves us closer to a meaningful peace. To achieve this, I propose a new cosmopolitan approach to animal rights, inspired by Kant's ethic of hospitality towards strangers found in his Perpetual Peace, and the idea that we should adopt a particular cosmopolitan mode of thinking, or Denkungsart, when legislating action-guiding rules. ${ }^{2}$

I begin with a short outline and defence of cosmopolitanism. Although my defence of cosmopolitanism is by necessity brief, further reasons to favour

1 Martha C. Nussbaum, 'The Moral Status of Animals', Chronicle of Higher Education 52, no. 22 (February 3, 2006): B6-8.

2 cf. Thomas E. Hill, Respect, Pluralism, and Justice: Kantian Perspectives (Oxford University Press, USA, 2000), 228. 
cosmopolitanism, particularly as an ethical standpoint towards non-human animals, are given in the course of the paper. Following this, I draw attention to cosmopolitan features of traditional animal rights theory, and demonstrate how it has nevertheless failed to fully commit to a cosmopolitan morality. In place of traditional similarity and 'let be' approaches, which I describe in detail below, I defend a non-anthropocentric cosmopolitan Denkungsart. The cosmopolitan Denkungsart informs specific rights to hospitable treatment, and duties of hospitality owed to all sentient beings - a ius cosmopoliticum for non-human animals. I finish by considering a range of potential problems with the cosmopolitan approach relating to its scope and its intellectual roots in Kant's logocentrism.

\section{Cosmopolitanism as a moral theory}

Cosmopolitans hold that we have basic moral obligations, owed to all people, and by virtue only of our shared humanity. Cosmopolitan principles are universal in scope and impartially applied. Furthermore, the cosmopolitan maintains that the primary locus of ethical concern is the individual rather than the state, group, or community. For the cosmopolitan, what marks out our humanity is not so much how we treat those nearest and dearest to us, but how we respond to strangers. After all, it is easy to act with compassion towards those whom we already love, it is harder to turn our faces from those who are known to us. Indeed, a good deal of moral theorising is devoted to reasons for overcoming feelings of partiality that might cause agents to wrongly favour those with whom they have emotional ties. Thus, we see in John Rawls' A Theory of Justice that his proposed means for assessing whether circumstances are just is through agents imagining whether they would agree to those circumstances being created if there were a chance that 
they would be the least advantaged by them. To do this agents imagine themselves unencumbered by personal attachments, knowledge of their place in society, and unaware of their comprehensive conceptions of the good. By thinking in this way, they are encouraged to consider the situation from an impartial standpoint. ${ }^{3}$ Similarly, we see Thomas Nagel's invocation of a powerful and benevolent being to illustrate how good should be distributed on an impartial and egalitarian basis to maximise the welfare of all. ${ }^{4}$

The reason for impartiality is grounded in the equal moral status accorded to all humans. Whilst moral agents can and do have special duties arising from ties of relationships, promises, agreements, and historical circumstances, these duties do not provide a firm footing for ethical behaviour. As Thomas Scanlon argues, whilst special relationships require that we act on the basis of special associative duties and our feelings towards those close to us, they also require that we recognise underlying moral standing apart from our relationships, which also constrains our actions towards others. ${ }^{5}$ The basic moral standing of a being qua that being is what makes it wrong, for example, to harm a stranger in order to benefit a loved one. Thus, we must begin from a position of equal treatment ${ }^{6}$ and are required to provide good reasons for differential treatment thereafter. What we owe to others as strangers is prior to what we owe to them by virtue of special associative duties, and these prior basic rights are by their nature both universal and held equally. Similarly, it is moral reasons rather than emotional responses that make creatures worthy of direct moral consideration. Rather than our

3 John Rawls, A Theory of Justice: Revised Edition (Cambridge, Massachusetts: Belknap Press of Harvard University Press, 1999), 15-19.

4 Thomas Nagel, Equality and Partiality (Oxford: Oxford University Press, 1991), 13-14.

5 Tom Scanlon, What We Owe to Each Other (Cambridge, Massachusetts: The Belknap Press of Harvard University Press, 1998), 165.

6 cf. James Rachels, The Elements of Moral Philosophy (New York: McGraw-Hill Humanities, Social Sciences \& World Languages, 2003), 11-14. 
sympathy for a particular creature providing the reason for us thinking it worthy of direct moral consideration, the fact that a creature is worthy of direct moral consideration gives us reasons to feel sympathy or compassion toward it. Sympathetic emotions are secondary to moral reasons. None of what I have written is meant to imply that emotional attachments or other special ties have no role to play in ethical thinking. Rather, that the fulfilment of duties arising from special obligations must be constrained by rights accorded as a matter of basic moral standing. It is on this basis that the cosmopolitan regards duties to others as individuals as reaching out beyond political borders and across cultures. As I go on to show in the next section, traditional animal rights theories are based on the thought that the moral standing of non-human animals has been incorrectly grounded in the identification of morally irrelevant differences. Cosmopolitanism not only allows us to address this arbitrary discrimination, but also speaks to the linked issue of marginalisation.

\section{Cosmopolitan animal rights}

Animal rights theories claim that non-human animals, as beings with a good of their own, also possess moral standing and thus are, like humans, owed duties for their own sake. Furthermore, animal rights theorists also claim that the rights held by non-human animals are basic and non-contingent; they hold regardless of their status in law, special relationships, or assumed obligations.

Much of the literature on animal rights is concerned with trying to find morally relevant similarities between humans and non-humans in order to show that differential treatment is often arbitrary. To do this, use is often made of what is known as the argument from marginal cases. The argument from marginal cases 
begins with the fact that there are no capacities that all humans and no animals possess, therefore, if we wish to use capacities such as rationality, language use, or intelligence as the basis for moral standing then we must exclude those humans, such as infants or the mentally incapable, who lack those capacities to the relevant degree. If we do not do this then we are being morally inconsistent and speciesist. For defenders of animals rights, the argument from marginal cases shows that we should not base moral standing on characteristics such as rationality, and should instead exercise consistency by picking a characteristic that does not arbitrarily exclude non-human animals. The morally relevant characteristic shared by both humans and animals is sentience. ${ }^{7}$

The argument from marginal cases is used by Peter Singer to argue for the equal consideration of interests of sentient beings regardless of species membership. ${ }^{8}$ Singer's utilitarian principles are impartially applied and from a universal standpoint. Meanwhile, Tom Regan argues for an impartial deontological ethic of animal rights that treats moral agents and moral patients as possessing equal inherent worth. ${ }^{9}$ Similarly, Gary Francione applies an equal consideration principle to non-human animals. ${ }^{10}$ By seeking universal and impartial non-speciesist moral principles, that treat moral agents and moral patients as formally equal, traditional animal rights theories go a considerable distance towards cosmopolitanism. However, there is also an accompanying tendency to resile from cosmopolitanism in two different directions. The first retreat from cosmopolitanism is in the form of what I label the similarity approach, and the

7 Peter Singer, Animal Liberation: Towards an End to Man's Inhumanity to Animals (London: Granada Publishing, 1977); Tom Regan, The Case for Animal Rights, 2nd ed. (Berkeley and Los Angeles: University of California Press, 2004).

8 Singer, Animal Liberation: Towards an End to Man's Inhumanity to Animals, 21-43.

9 Tom Regan, Defending Animal Rights (Champaign, IL: University of Illinois Press, 2001), 128-129 and 235-244.

10 Gary L Francione, 'Animals as Property', Animal Law 2 (1996): 22-40. 
second, the 'let be' approach. The similarity approach constructs an ethical argument for the treatment of non-human animals around perceived similarities in their existences with those of humans, whilst the 'let be' approach argues that humans and non-human animals should live in separate moral and physical spheres. Whilst anti-speciesist arguments in the animal rights literature do lend themselves to cosmopolitan thinking, the two strands above represent ways of thinking, and lead to action-guiding principles, that are in conflict with cosmopolitanism. No only that, but each approach is internally problematic in ways that can be resolved through cosmopolitanism. In what follows I discuss the similarity approach and 'let be' approach in greater detail, drawing out problems with them and tensions with cosmopolitanism. I then move on to present a species-blind cosmopolitanism as a way of resolving these highlighted problems. ${ }^{11}$

\section{The similarity approach}

In the animal rights literature, authors often identify similarities between humans and non-human animals. By finding similarities we are able to build connections, to identify with non-human animals and understand their plight. If they are like us in some respect, and we like them, then it becomes easier for us to place ourselves in their situations. Similarities stimulate empathy and compassion - they make the functioning of our moral imaginations easier. In this way the similarity approach ${ }^{12}$ attempts to demonstrate that non-human animals are 'like us' in some respect by

11 I should make clear that Singer's ethical approach to non-human animals is not vulnerable to the criticisms of animal rights theory that I raise. Because Singer relies upon utilitarian reasoning and is concerned with maximising preference satisfaction as a measure of utility, his ethic is not strictly rights based. Nevertheless, I mention his equal consideration of interests principle above because his arguments have been so influential across ethical theories regarding non-human animals.

12 Whilst arguments such as the argument from marginal cases presented above may seem like strands of similarity approach, rather than identifying similarities as a means of engaging our moral imaginations they instead represent an attempt to achieve coherence and consistency between moral beliefs, and to avoid post-hoc arbitrariness in moral reasoning. 
highlighting behaviours and characteristics that resemble human characteristics, such as the use of language, social behaviour, moral emotions, or familiar seeming behaviours. ${ }^{13}$

The similarity approach is in seeming contradiction with the search for morally relevant characteristic that do not arbitrarily exclude certain beings from moral consideration. In moving from locating moral standing in sentience, to identifying ways in which non-human animals nevertheless possess the very characteristics that have been rejected as being the foundation for inherent moral worth, animal rights theorists appear to be performing a volte-face. Nevertheless, this move is at least understandable: it forms what Chris Cuomo and Lori Gruen refer to as an 'ethical starting point' from which to bridge moral difference. ${ }^{14}$ Ethical starting points, such as the cultivation and recognition of relationships of friendship or love with non-human animals, assist in the development of non-speciecist moral outlooks. ${ }^{15}$ The cultivation of relationships, argues Kennan Ferguson, also helps us to overcome problems of moral motivation that the pure exercise of reason (as we seen in the argument from marginal cases) does not. ${ }^{16}$ Accepting the arguments of Cuomo, Gruen, and Ferguson, there nevertheless remain problems with this relationship-focussed approach.

13 For examples of this similarity approach see: Thomas I. White, In Defense of Dolphins: The New Moral Frontier (Oxford: Wiley-Blackwell, 2007); Maddalena Bearzi and Craig Britton Stanford, Beautiful Minds: The Parallel Lives of Great Apes and Dolphins (Cambridge, Massachusetts \& London, England: Harvard University Press, 2008); Mark Gold, Animal Rights: Extending the Circle of Compassion (Oxford: John Carpenter Publishing, 1995), chap. 1, § 3; Alison Hills, Do Animals Have Rights? (Cambridge: Icon Books, 2005), chap. 5; Steven M. Wise and Jane Goodall, Rattling the Cage: Toward Legal Rights for Animals (Cambridge, Massachusetts: Persius Publishing, 2000), chap. 10.

14 Chris J. Cuomo and Lori Gruen, 'On Puppies and Pussies: Animals, Intimacy, and Moral Distance', in Daring to Be Good: Essays in Feminist Ethico-Politics, ed. Bat-Ami Bar On and Ann Ferguson (New York and London: Routledge, 1998).

15 Ibid.

16 Kennan Ferguson, 'I $\$ My Dog', Political Theory 32, no. 3 (January 6, 2004): 380-383. 
In a section that brings to mind Nagel's famous paper 'What is it like to be a bat' ${ }^{17}$ Ferguson raises the problem that: 'Humans and dogs live in fundamentally different worlds, where even the very methods of communication and connection are so disparate as to be untranslatable ${ }^{18}$. Whilst Ferguson argues that, in the case of human encounters with dogs, love and trust remain possible in spite of the existential gulf between species, it is unlikely that the same can be said for our encounters with all other sentient species: can one truly form a trusting or loving relationship with a platypus, rattlesnake, or bat? Furthermore, pursing this strategy of building relationships and locating shared identity as the starting point of moral inquiry is open to the criticism of partiality raised by Scanlon earlier. In constructing shared identities, we look to the aspects of our identity that we hold in common, and at the same time we identify differences in those outside the our groups. Identity is as much a concept of difference as it is of similarity. ${ }^{19}$ Those animals which we struggle to imagine consuming or treating as mere means to our ends, are those that we have brought into our households and made part of our families. They are those whom we have come to love for their own sakes. The abhorrence that so many in the West feel at the eating of dogs arises because we have constructed an identity for dogs as companion animals. ${ }^{20}$ Because we have come to imagine them as potential family members, guards, or helpers rather than as potential meals, the idea that they can be eaten is shocking to us. On the one hand, the way that we respond to dogs as potential companion animals shows us that we can build meaningful and reciprocal relationships with other animals, but

17 Thomas Nagel, 'What Is It Like to Be a Bat?', The Philosophical Review 83, no. 4 (October 1, 1974): 435-450.

18 Ferguson, 'I円My Dog', 375.

19 For a good discussion of this topic see Amartya Sen, Identity and Violence: The Illusion of Destiny (London: Penguin Books, 2007).

20 cf. Cora Diamond, 'Eating Meat and Eating People', Philosophy 53, no. 206 (October 1978): 465-479. 
on the other, it demonstrates that such relationships provide unstable foundations for the moral standing of non-human animals. Having outlined the similarity approach, I now turn to the 'let be approach' as a prelude to discussing the cosmopolitan Denkungsart. The 'let be approach' is concerned with how political communities, as well as individuals, should interact with other species,

\section{The 'let be' approach}

In a their recent book, Zoopolis: a political theory of animal rights, Sue

Donaldson and Will Kymlicka have highlighted that the reality of our shared existence means that a theory of animal rights which does not address how political communities should interact with animals is lacking. They draw attention to the tendency in traditional animal rights theory to adopt a 'let be' approach that calls for humans and animals to live separate lives through the ending of domestication and the protection of wilderness areas. One can see this thread of traditional animal rights theory beginning in the work of Tom Regan. Regan argues that there is a 'wild', inhabited by non-human animals, that humans should refrain from interfering in. ${ }^{21}$ This this theme re-occurs in Aaron Simmons' insistence that 'human society and the wild constitute "different worlds", 22 and again in the Jennifer Everett's discussion of predation. ${ }^{23}$ Likewise, Francione's call for an end to domestication, such that all political interactions with non-human animals become wilderness interactions,${ }^{24}$ represents yet another instance of the 'let be' approach.

21 Regan, The Case for Animal Rights, xxxvii-xxxviii and 357-361.

22 Aaron Simmons, 'Animals, Predators, the Right to Life, and the Duty to Save Lives', Ethics \& the Environment 14, no. 1 (2009): 23.

23 Jennifer Everett, 'Environmental Ethics, Animal Welfarism, and the Problem of Predation: A Bambi Lover's Respect For Nature', Ethics \& the Environment 6, no. 1 (2001): 42-67.

24 Gary Lawrence Francione, Animals as persons : essays on the abolition of animal exploitation (New York: Columbia Univ. Press, 2008), 164. 
One of the reasons Donaldson and Kymlicka believe that such approaches have failed to significantly capture the imagination, despite being grounded in convincing arguments for granting rights to non-human animals, is that the 'let be' approach does not reflect the reality that humans and non-human animals can live mutually enriching lives together, and further, that co-existence is also desirable. ${ }^{25}$ With this argument Donaldson and Kymlicka speak to the same problem of reconciling reason and moral motivation addressed by Ferguson above. Their solution differs from that of Ferguson, Cuomo and Gruen, however, in that it focusses on political rather than personal relationships as the means of overcoming this problem.

It is true that, at the very least, humans cannot avoid encounters with other species; and, because non-human animals are worthy of consideration for their own sakes, those encounters should be guided by moral principles. Given the inescapable reality of finite geography, the 'let be' approach cannot help but be insufficient. Whilst Donaldson and Kymlicka conduct their analysis at the level of the nation state, their argument for thinking of animal rights as a political project provides a compelling reason to pursue a more cosmopolitan approach to animal rights at the global level. The reason for this is that whilst they are correct in identifying the need for political principles governing interactions with animals, their solution builds in some of the same problems that the similarity approach suffers from. Because their analysis is focussed upon making citizens and sovereigns of non-human animals, they are in danger of pushing those animals not regarded as citizens out of the sphere of moral concern. In the attempt to bring animals in by making them part of the polity, Donaldson and Kymlicka

25 Sue Donaldson and Will Kymlicka, Zoopolis: A Political Theory of Animal Rights (Oxford and New York: Oxford University Press, 2011) passim. 
simultaneously risk simply altering ways in which people think of non-human animals as different. Thus, I share the cosmopolitan concern, articulated by Hannah Arendt in The Origins of Totalitarianism, that when rights are enforceable through nation states, those who are stateless drop out of the moral landscape and become vulnerable and marginalised. ${ }^{26}$ Just as nothing sacred is found 'in the abstract nakedness of being human', ${ }^{27}$ so too is sacredness absent in the abstract status of the stateless non-human animal. Nevertheless, Donaldson and Kymlicka's project is a worthy one, and I do not wish to overstate my concern with their citizenship approach. The dangers in their approach are connected with the ethical perspective that comes with looking outward from the nation-state, rather than the aim of raising the moral standing of non-human animals by making them members of the domestic polis. It is to avoid exclusion from moral concern, which identities based on similarity and difference bring with them, that we should adopt the cosmopolitan Denkungsart.

\section{The cosmopolitan Denkungsart}

The similarity approach that I have described represents a mindset of seeking to overcome difference in order to extend the circle of compassion. The 'let be' approach imagines a gulf between human and animal existence and demands separation between human communities and animal lives. One approach draws humans and other animals together, the other pushes them apart. Overcoming the problems of the 'let be approach' by bringing non-human animals into the national political community is attractive, but has some of the same vulnerabilities as each of those two approaches. Instead of, or prior to, pursuing these courses, animal

26 Hannah Arendt, The Origins of Totalitarianism (London and New York: Meridian Books, 1958), 295-296.

27 Ibid., 299. 
rights theorists should accept and accommodate the non-autonomous nature of non-human animals into the cosmopolitan Denkungsart. ${ }^{28}$ The Denkungsart is the attitude, arising out of the exercise of reason, that one takes in regard of the moral law. ${ }^{29}$ The cosmopolitan Denkungsart involves both a willingness to engage with others in a peaceful and open manner, and an attitude of accepting difference. In particular, it includes an ethic of approaching and responding to strangers.

A stranger is someone who is unfamiliar to us, someone with whom we have no connection or personal relationship. In political terms, a stranger is someone with whom we do not share a national identity - an alien, a foreigner, an outsider. Because we have no relationship with the stranger, and share no political identity, we have no feelings of partiality towards them. Thus, when we act partially towards those with whom we are enmeshed in a relationship or shared identity, and in a way that is unwarranted, it is the stranger whom we wrong. By unwarranted partiality I mean the kinds of acts of partiality that violate the rights of the stranger or are unfair because they arbitrarily favour one party in spite of other morally relevant considerations. ${ }^{30}$

Non-human animals are strangers in the sense that they are both an unknown quantity, and someone with whom we share no identity or relationship. At a political level non-human animals are excluded from being fully part of the national identity for, while they can form part of that identity, ${ }^{31}$ they cannot hold

28 Georg Cavallar, Kant and the Theory and Practice of International Right (Cardiff: University of Wales Press, 1999), 144.

29 Henry E. Allison, Kant's Groundwork for the Metaphysics of Morals:A Commentary (Oxford: OUP Oxford, 2011), 79.

30 An example of such a case might be giving a job to a lazy friend with no talent for the role at the expense of hard-working and better qualified stranger. For a discussion on legitimate partiality see Susan Wolf, 'Morality and Partiality', Philosophical Perspectives 6 (1992): 243-259.

31 Think of the importance held by native species in political discourse about conservation, and the supposed threat ascribed to non-native or 'invasive' species. 
or assert it for themselves. Thus, non-human animals are strangers in sense that they are outsiders to the community. True, we can go some way towards building relationships with them by inviting them into our homes and our families, and we may communicate with them in some limited fashions, but we will never share the kind of identities with them that help give meaning to political communities, citizenship, or self-determination. Therefore, political principles governing interactions with non-human animals need to account for this fact. What is more, non-human animals are strangers because the gulf in understanding between their minds and ours, which Ferguson points to, makes them unknowable and prevents deep communication. These two characteristics of animal existence mean that animals can be thought of as the paradigmatic stranger, and it is they who we wrong when we act with unwarranted partiality towards our own species.

Traditionally, the cosmopolitan mindset involves looking beyond the otherness of the stranger to see the common humanity in them. Thus, for the cosmopolitan, the 'other' may be culturally different, but they remain human, and that is sufficient to require moral consideration. At the same time, the cosmopolitan, by defining identity in terms of humanity, marks out points of difference with non-human animals: humans are rational, moral, intelligent, cultured, creative, language users, etc., animals are instinctive, amoral, beastly, and so forth. Whilst this identification, taken in itself, is a normatively neutral act, the argument from marginal cases demonstrates how problematic it can be when it informs or becomes the driver for ethical reasoning. Animal rights theorists have shown that the bare fact of shared genetic data is not a morally relevant fact upon which to justify differential treatment, and neither are there any characteristics or capabilities shared by all humans and no non-humans that are. Rather, it is our 
capacity to feel pain, suffer, and have a good of our own that binds us together at the most basic level. Thus, the cosmopolitan must do more than simply look beyond national citizenship or community, but they must also look beyond species membership.

\section{The animal ius cosmopoliticum}

The cosmopolitan Denkungsart is a way of thinking, an orientation one adopts when deliberating on action-guiding rules. Thus, one might reasonably ask what adopting and cultivating the cosmopolitan mindset means in terms of practical political action? In keeping with the themes from Kant's Perpetual Peace, I begin with the duty to act hospitably towards non-human animals.

In Perpetual Peace, Kant develops an ethic of responding to strangers: the cosmopolitan right, this ethic forms the inspiration here for a ius cosmopoliticum for non-human animals. The cosmopolitan right means accepting that we share this world with others, many of whom will be strangers with whom conflict or disagreement is inevitable. In order to live in peace we must come to terms with our differences and adopt a principle of 'universal hospitality'. In 'What is Cosmopolitan?' Jeremy Waldron discusses Kant's treatment of strangers, and he remarks on the tendency of humans to accompany their movement across the globe, and settlement of territories, with exploitation, slavery, and extermination. ${ }^{32}$ Humans are bound to encounter others they share little with and struggle to understand, but nevertheless Kant argues that we each have a right to seek fair terms or cooperation or coexistence from those we encounter: 'so long as he

32 Jeremy Waldron, 'What Is Cosmopolitan?', Journal of Political Philosophy 8, no. 2 (June 1, 2000): 237. 
conducts himself peaceably, he must not be treated as an enemy ${ }^{\prime 33}$. As humans have spread across the globe, inhabiting more and more of the finite space available, they have wrought devastation on the habitats and populations of non-human animals. In Perpetual Peace Kant notes how primitive man makes 'war against wild animals' ${ }^{34}$, and in many ways it does not seem that what we do to them now is so very different; the cosmopolitan approach to ending conflict between humans can also help us resolve how we interact with non-human animals on fair terms. Extending the cosmopolitan Denkungsart to encompass ethical concern for non-human animals means accepting that the duty of hospitality is non-speciesist.

The right to hospitable treatment applies in two different ways. The first is where animals enter into the political communities of human beings, either as migratory animals, or through simply straying into our spaces in search of food or shelter. In these cases the right to be treated peaceably, so long as they do not act with hostility, applies. Thus, the duty of hospitality does not require humans to allow in the malarial mosquito, or dangerous predator. Rather it requires us to stave off hostility and make limited accommodations where non-human animals pose little threat to us. It certainly imposes a duty to grant moral weight to the needs and interests of peaceful animals and for our response to them to be mindful of these interests. As an extension to this, the duty of hospitality to strangers can also form the basis of a just domestication of non-human animals. Kant argues that, after presenting themselves, strangers can enter into agreements: '[t]hese relations may at last come under the public control of law, and thus the human race may be

33 Kant, Perpetual Peace, 18.

34 Immanuel Kant, Perpetual Peace: A Philosophical Essay, trans. Mary Campbell Smith (New York and London: Cosimo, Inc., 2010), 22. 
brought nearer the realization of a cosmopolitan constitution. ${ }^{35}$ Clearly, non-human animals cannot literally enter into agreements, but they can express preferences, and can live beneficial and enriching lives as domesticated animals in ways that, were they able to consent, they may well have agreed to. Thus, some form of hypothetical consent can be imagined to determine the just parameters of a relationship in a manner similar to the Rawlsian contracting process discussed earlier. $^{36}$

The second case where political principles are needed to govern our interactions with non-human animals is where human activities spill into the territories of free-ranging animals in the wilderness. As Kant writes, because the earth is a globe 'we cannot be infinitely scattered, and must in the end reconcile ourselves to existence side by side: at the same time, originally no one individual had more right than another to live in any one particular spot. ${ }^{137}$ Clearly, animals cannot strictly be hospitable to us; not being moral agents, they cannot be duty bearers. Humans however, can approach them peacefully, using violence only in response to threat, and acting in ways that avoid or minimise harm to them. In other words, when we enter the territories of non-human animals, we should behave as if we are their guests, respecting their claims as we do so. These different ways of interacting with animals result in conclusions which closely align to those reached by Donaldson and Kymlicka, ${ }^{38}$ but where they arrive at them by re-conceiving citizenship and sovereignty, taking the individual situated within the nation-state

35 Ibid., 18-19.

36 For some articulations of such approaches see Rowlands M. [1], 'Contractarianism and Animal Rights', Journal of Applied Philosophy 14 (November 1997): 235-247; Peter S. Wenz, Environmental Justice (Albany: SUNY Press, 1988); Ruth Abby, 'Rawlsian Resources for Animal Ethics', Ethics \& the Environment 12, no. 1 (2007): 1-22; Robert Garner, 'Animals, Politics and Justice: Rawlsian Liberalism and the Plight of Non-humans', Environmental Politics 12 (June 2003): 3-22.

37 Kant, Perpetual Peace, 18.

38 Donaldson and Kymlicka, Zoopolis: A Political Theory of Animal Rights. 
as the starting point for political theorising, my approach begins from the universal, global standpoint and requires no drastic re-working of such familiar political concepts.

\section{Problems with extending cosmopolitanism}

One of the reasons Kant gives for the right to hospitable treatment is that there is a 'common right of possession of the surface of the earth'. ${ }^{39}$ One worry might therefore be that non-human animals cannot be owed duties of hospitality since they cannot be owners of things. The critic could therefore succeed in his argument by showing that is conceptually incoherent to think of animals as property owners. However, to do so is not so easy. One hears, for example, of beloved pets being bequeathed property in the wills of their owners. In such cases trustees are appointed to ensure that property is managed in the interests of the animal to which it belongs, just as it is in the case of humans lacking the capabilities to exercise property rights for themselves. If the incidences of ownership associated with property rights can be managed by a guardian on behalf of a non-human animals, ${ }^{40}$ then there seems no obvious reason why we cannot, in principle, regard the earth as held in common with non-human animals, or consider the the claims of non-human animals over territories currently regarded as unowned. Indeed, there may be a case to be made that a great deal of land currently owned by humans has been unjustly acquired in the first instance from non-human animals with a stronger claim than the humans who appropriated it. In an unpublished paper, Ben Saunders has argued that traditional liberal

39 Kant, Perpetual Peace, 18.

40 cf. John Hadley, 'Nonhuman Animal Property: Reconciling Environmentalism and Animal Rights', Journal of Social Philosophy 36, no. 3 (2005): 305-315; see also W.D. Lamont, Principles of Moral Agreement (Oxford: Oxford University Press, 1946), 83-85. 
theories of acquisition do not necessarily exclude non-human animals from acquiring land, and that one can imagine how the activities of, for instance, a beaver damming a river might figure in a labour mixing argument, or that first occupancy principles can easily accommodate non-human animals. ${ }^{41}$ Similarly, John Hadley points the ways in which non-human animals demarcate their territories as a recognisable claim. ${ }^{42}$ Additionally, he argues that, under an interest theory of rights, the fulfilment of basic needs is considered sufficient normative justification for ownership and usufructary rights over land and natural resources. ${ }^{43}$ Since non-human animals have the same interests in having their basic needs met, the normative justification for property rights will apply to them too. ${ }^{44}$ Not only is it conceptually coherent to regard non-human animals as potential property owners, but it can be shown that they also have legitimate claims to land and natural resources. Therefore, the claim that a cosmopolitanism premised on ownership rights to the earth necessarily excludes non-human animals does not succeed.

A more serious concern than the ownership issue, is that Kant's attachment to reason as the source of value makes using his body of work as the inspiration for an ethic of animal rights problematic. For Kant, we are obligated to others only out of the moral requirement to respect the humanity in persons, which derives from the distinctive attributes of moral personhood: rationality and the power to set ends. ${ }^{45}$ Thus, the cosmopolitan right is arrived at because persons can legislate

41 Ben Saunders, 'Animals and World Ownership (unpublished)' (presented at the Manchester Centre for Political Thoery Seminar Series Autumn 2010, The University of Manchester, 2010)

42 Hadley, 'Nonhuman Animal Property: Reconciling Environmentalism and Animal Rights', 309.

43 Ibid., 309-310.

44 Ibid.

45 Thomas E. Hill, 'Humanity as an End in Itself', Ethics 91, no. 1 (October 1980): 85-86. 
and abide by moral rules, and, being the only kinds of beings that can be bound by duties, they are also the only kinds of beings deserving of duties. Although there is some inconsistency in Kant's treatment of non-human animals, ${ }^{46}$ Kant's broad principles, and his most explicit piece of writing on the subject, ${ }^{47}$ do lead to position that supports only indirect duties to non-human animals. Does this mean that a cosmopolitan approach to animal rights, inspired by Kant, cannot succeed? Far from it. There are four obvious routes one can take to reject this claim.

The first route is to accept Kant's argument that duties to non-human animals are really duties to humans; that treating non-human animals badly leads to treating humans badly. Accepting this argument provides us with prudential reason for treating animals well, and can lead to strong duties to non-human animals. ${ }^{48}$ For example, one might look at the body of evidence suggesting a link between animal cruelty and domestic violence, ${ }^{49}$ and conclude that treating non-human animals as if they were owed direct duties best serves the aim of arriving at a perpetual peace.

A second route would be to accept Kant's premise that reason is the source of value, but reject his conclusion that it must also therefore be its terminus. In this vein we see arguments from Allen Wood and Onora O'Neill, that respecting

46 cf. Allen W. Wood and Onora O’Neill, 'Kant on Duties Regarding Nonrational Nature', Proceedings of the Aristotelian Society, Supplementary Volumes 72 (January 1, 1998): 191, 202; Christine Korsgaard, 'Interacting with Animals: a Kantian Account', in The Oxford Handbook of Animal Ethics, ed. Tom L. Beauchamp and R. G. Frey (Oxford: Oxford University Press, 2011), 99-100.

47 Immanuel Kant, 'Duties to Animals Are Indirect', in Animal Rights: a Historical Anthology, ed. Andrew Linzey and Paul Clark (New York: Columbia University Press, 2004).

48 For such an argument see Lara Denis, 'Kant's Conception of Duties Regarding Animals: Reconstruction and Reconsideration', History of Philosophy Quarterly 17, no. 4 (October 2000): 405-423.

49 See, for example Andrew Linzey, The Link Between Animal Abuse and Human Violence (Brighton [England] ; Portland, Ore.: Sussex Academic Press, 2009) and; Randall Lockwood and Frank R. Ascione, Cruelty to Animals and Interpersonal Violence: Readings in Research and Application (est Lafayette, Ind.: Purdue University Press, 1998). 
rationality also requires respecting its necessary conditions, such as sentience, and those are also present in non-human animals. ${ }^{50}$ Similarly, Christine Korsgaard argues that when a rational actor confers value upon their own ends and in so doing thus asserts their own value, the self that they value is more than merely the rational component of their being. Rather, it is both the rational and animal nature of the agent, and this is so because many of our interests are not rationality dependent (such as our interest in not experiencing pain). The rational agent, in respecting herself, and thus presenting a claim that others should also respect her, takes both her rational and non-rational selves to be good. In other words, the good of rational beings includes rationality, but is not limited by it, and therefore rational agents must take sentience to be objectively and normatively good for non-rational creatures as well. ${ }^{51}$

Alternatively, one could take the third route and reject parts of Kant's argument, such as that rationality is the sole source of value, but accept others. Taking this route might lead us to accept animal claims to ownership of the planet, as outlined above, or to pursue non-violence for some other reason than that rational agents have value conferred upon them by their capacity to legislate.

Finally, one might adopt a looser conception of rational or moral personhood than Kant and thus include some non-human animals within the category of beings valuable for their own sakes from within a Kantian perspective. Personhood is both a property possessed in degrees (both between individuals and during an individual's life-span), and one which is conceived in different ways. Beings

50 Onora O'Neill, 'Kant on Duties Regarding Nonrational Nature', Aristotelian Society Supplementary Volume 72, no. 1 (1998): 211-228; Wood and O’Neill, 'Kant on Duties Regarding Nonrational Nature'; for a counter argument see James Skidmore, 'Duties to Animals: The Failure of Kant's Moral Theory', The Journal of Value Inquiry 35, no. 4 (December 1, 2001): 541-559.

51 Korsgaard, 'Interacting with Animals: a Kantian Account', 107-109. 
possessed of the necessary capacities for personhood to certain degrees may be able to set, pursue and revise goals, and reason to a limited degree, but nevertheless lack sufficient moral personality to be held accountable for their actions. Thus, whilst lacking moral culpability, we could nevertheless argue that some non-human animals possess personhood to a degree sufficient for it to form a component of their good, and it therefore could be more appropriate to think of intelligent beings, such as the Great Apes as partial persons than non-persons.

Each of these four routes, although requiring much fuller arguments than I have given, provide reasons for thinking that it is possible to extend Kant's cosmopolitanism to other animals than just humans. There are good reasons to take one or more of these routes, not least because the logic of Kant's argument itself falls foul of the argument from marginal cases and leads to the undesirable conclusion that non-rational humans are owed only indirect duties.

One final potential objection to extending cosmopolitan principles to non-human animals is that cosmopolitanism is conceived by contemporary cosmopolitans as a democratic ideal. Cosmopolitanism is regarded as embodying and expressing the value of autonomy of the individual, who is seen as both free and equal. ${ }^{52}$ The concern of cosmopolitans is partly to ensure that the autonomous individual can be part-author of the decisions and directions taken by their communities through participation in democratic decision-making. Whether it is the thoroughgoing cosmopolitanism of David Held, or the rooted or bounded cosmopolitanism of Will Kymlicka, the importance of protecting individual autonomy and democratic self-determination is of central importance..$^{53}$ In this respect contemporary

52 David Held, 'The Principles of Cosmopolitan Order', in The Cosmopolitanism Reader, ed. Garrett Wallace Brown and David Held (Cambridge: Polity, 2011), 230.

53 Held, 'The Principles of Cosmopolitan Order'; Will Kymlicka, Politics in the Vernacular 
cosmopolitanism is grounded in the same view of the human as a moral agent adopted by Kant, which also makes it vulnerable to the criticism that it is insensitive to the needs of non-rational sentient beings, whether they be humans or otherwise. Writers like Donaldson and Kymlicka have attempted address this complaint by broadening notions of cooperation, authorship, reciprocity, and autonomy so that those living within a community, but who lack moral personhood, can be considered as participating citizens. ${ }^{54}$ However, there is a risk associated with their endeavour that the meaning of concepts like autonomy become over attenuated to the point that they lose their distinctive normative relevance. For non-human animals, and non-rational humans, the importance of freedom is unconnected with being able to rationally pursue, set, and revise life plans in pursuit of chosen goods. The value of liberty embodied in democratic principles therefore loses normative force when applied to non-human animals for whom the interest in liberty is qualitatively different. Cosmopolitan ideals therefore can, and should be, decoupled from democracy where autonomous choice does not form part of a being's good. If cosmopolitanism is concerned with the fulfilment of duties and protection of rights, and those rights and duties depend upon the needs or capabilities of the objects of our ethical concern, then there is no pressing reason to think of a commitment to democratic principles as a necessary condition of the cosmopolitan ideal.

\section{Limits of the ius cosmopoliticum}

What then are the limits of the cosmopolitan ethic? In part this question is answered by the animal rights approach taken, and the use I have made of the

(Oxford: Oxford University Press, 2001).

54 Donaldson and Kymlicka, Zoopolis: A Political Theory of Animal Rights, chap. 5. 
argument from marginal cases. Traditional animal rights theories insist, as far as fundamental rights or basic duties are concerned, first, that we should treat like cases alike and second, that equally sentient human and non-human animals are like cases. Thus, a species-blind ius cosmopoliticum and cosmopolitan Denkungsart does not extend to non-sentient things such as plants, ecologies, or the environment. Nor does it extend to categories of things separate from their individual members. So, it encompasses individual animals, but not species of animals considered valuable apart from the individuals that constitute those species.

Nevertheless, it could still be said that a cosmopolitan theory of animal rights is overly demanding. If cosmopolitan principles provide positive obligations across borders in the human case, then might they require us to intervene when animals are threatened either by humans, other animals, or natural disasters? Insofar as cosmopolitan principles are political principles, then in many cases the answers are likely to be 'yes'. However, with the exception of predation, ${ }^{55}$ the constraints and problems with such interventions will be very similar to those faced in traditional humanitarian cases. Cosmopolitan approaches to Just War Theory, humanitarian intervention, international aid, etc., can be applied to animals in need $^{56}$ with little modification needed. For example, one might ask, before intervening to save threatened animals, upon whom the duty of intervention falls,

55 Whether we have a political duty to intervene in cases where animals are being predated by one another is more complex than cases of human persons killing one another because non-human animals are not moral agents and thus should be regarded as innocent attackers. However, whilst this presents a difficult problem to resolve at the level of individual action (one which I lack space to discuss), it is far less an issue for political communities. Simply because one country has a high number of murders or other rights violations does not necessarily impose a duty upon other nations to intervene in its affairs. The same is true in the case of wild animal predation, other conditions must first be met before intervention is justified or permissible.

56 see J Hadley, 'The Duty to Aid Nonhuman Animals in Dire Need', Journal of Applied Philosophy 23, no. 4 (2006): 445-451 for a treatment of the duty to aid animals in need. 
what the likely chance of success is, whether there is legitimate authority for intervention, and so forth. Thus, whilst there are difficulties in knowing what the limits of action required by cosmopolitan principles are, they are not substantially different in respect of non-human animals than in human cases. ${ }^{57}$ If a species-blind cosmopolitanism is overly-demanding, then it will therefore be overly-demanding for the same reasons that an anthropocentric cosmopolitanism will be. For this reason, I will not defend my thesis against this specific charge any further. Instead, I now move to some concluding remarks.

\section{Conclusion}

Earlier, I stated my agreement with Donaldson and Kymlicka, and with Nussbaum, that theories of animal rights need to consider issues of justice and how political communities interact with animals. I have argued that we do not have to begin our approach to the animal rights issue by seeking similarities between ourselves and animals, or by building relationships with them. Rather, we should seek universal and impartial principles to form the foundations upon which we build such relationships. For cosmopolitans and animal rights theorists alike, there are good reasons to do so. Contemporary cosmopolitans, drawing from Kant and Erasmus, have tended to focus the cosmopolitan project at promoting and ensuring a peaceful world order. However, discussion of the rights of non-human animals has been largely absent from cosmopolitan discourse. Because of this, the cosmopolitan peace is one which is paradoxically tolerant of almost incomprehensible levels of industrialised violence against tens of billions of sentient beings every year. By ignoring the plight of non-human animals, and

57 For some potential political requirements concerning predation, see Tyler Cowen, 'Policing Nature', Environmental Ethics 25, no. 2 (2003): 169-182. 
drawing the boundaries of ethical concern based upon common humanity, cosmopolitanism is vulnerable to the charge of speciesism. Meanwhile, similarity and 'let be' approaches in animal rights theory risk being inconsistent with sentience-based justifications for equal consideration.

Not only are initial encounters with non-human animals engagements with strangers, but the existential gulf between us means that they will always be strangers to some degree. Because of this, we should consider animal ethics from a cosmopolitan mindset and seek cosmopolitan principles governing our interactions with animals. The cosmopolitan Denkungsart informs the species-blind ius cosmopoliticum. Animals have a right not to be treated as enemies when they pose no threat to us. If we think of some of the basic human rights as an implementation of the Kantian principle of the right of hospitality, and if we imagine non-human animals as almost perpetual strangers, then the animal liberation movement can be conceived of as the natural end-point of cosmopolitanism. Being humanitarian should not just mean protecting the human, it should also mean acting with humanity towards all sentient beings. 


\section{References}

Abby, Ruth. 'Rawlsian Resources for Animal Ethics'. Ethics \& the Environment 12, no. 1 (2007): 1-22.

Allison, Henry E. Kant's Groundwork for the Metaphysics of Morals:A Commentary. Oxford: OUP Oxford, 2011.

Arendt, Hannah. The Origins of Totalitarianism. London and New York: Meridian Books, 1958.

Bearzi, Maddalena, and Craig Britton Stanford. Beautiful Minds: The Parallel Lives of Great Apes and Dolphins. Cambridge, Massachusetts \& London, England: Harvard University Press, 2008.

Cavallar, Georg. Kant and the Theory and Practice of International Right. Cardiff: University of Wales Press, 1999.

Cowen, Tyler. 'Policing Nature'. Environmental Ethics 25, no. 2 (2003): 169-182.

Cuomo, Chris J., and Lori Gruen. 'On Puppies and Pussies: Animals, Intimacy, and Moral Distance'. In Daring to Be Good: Essays in Feminist Ethico-Politics, edited by Bat-Ami Bar On and Ann Ferguson. New York and London: Routledge, 1998.

Denis, Lara. 'Kant's Conception of Duties Regarding Animals: Reconstruction and Reconsideration'. History of Philosophy Quarterly 17, no. 4 (October 2000): 405-423.

Diamond, Cora. 'Eating Meat and Eating People'. Philosophy 53, no. 206 (October 1978): 465-479.

Donaldson, Sue, and Will Kymlicka. Zoopolis: A Political Theory of Animal Rights. Oxford and New York: Oxford University Press, 2011.

Everett, Jennifer. 'Environmental Ethics, Animal Welfarism, and the Problem of Predation: A Bambi Lover's Respect For Nature'. Ethics \& the Environment 6, no. 1 (2001): 42-67.

Ferguson, Kennan. 'I円My Dog'. Political Theory 32, no. 3 (January 6, 2004): 373-395.

Francione, Gary L. 'Animals as Property'. Animal Law 2 (1996): i.

Francione, Gary Lawrence. Animals as persons : essays on the abolition of animal exploitation. New York: Columbia Univ. Press, 2008.

Garner, Robert. 'Animals, Politics and Justice: Rawlsian Liberalism and the Plight of Non-humans'. Environmental Politics 12 (June 2003): 3-22.

Gold, Mark. Animal Rights: Extending the Circle of Compassion. Oxford: John Carpenter Publishing, 1995.

Hadley, John. 'Nonhuman Animal Property: Reconciling Environmentalism and Animal Rights'. Journal of Social Philosophy 36, no. 3 (2005): 305-315.

Hadley, J. 'The Duty to Aid Nonhuman Animals in Dire Need'. Journal of Applied Philosophy 23, no. 4 (2006): 445-451.

Held, David. 'The Principles of Cosmopolitan Order'. In The Cosmopolitanism Reader, edited by Garrett Wallace Brown and David Held. Cambridge: Polity, 2011.

Hills, Alison. Do Animals Have Rights? Cambridge: Icon Books, 2005.

Hill, Thomas E. 'Humanity as an End in Itself'. Ethics 91, no. 1 (October 1980): 84-99.

James Rachels. The Elements of Moral Philosophy. New York: McGraw-Hill Humanities, Social Sciences \& World Languages, 2003. 
Kant, Immanuel. 'Duties to Animals Are Indirect'. In Animal Rights: a Historical Anthology, edited by Andrew Linzey and Paul Clark. New York: Columbia University Press, 2004.

. Perpetual Peace: A Philosophical Essay. Translated by Mary Campbell Smith. New York and London: Cosimo, Inc., 2010.

Korsgaard, Christine. 'Interacting with Animals: a Kantian Account'. In The Oxford Handbook of Animal Ethics, edited by Tom L. Beauchamp and R. G. Frey. Oxford: Oxford University Press, 2011.

Kymlicka, Will. Politics in the Vernacular. Oxford: Oxford University Press, 2001.

Lamont, W.D. Principles of Moral Agreement. Oxford: Oxford University Press, 1946.

Linzey, Andrew. The Link Between Animal Abuse and Human Violence. Brighton [England]; Portland, Ore.: Sussex Academic Press, 2009.

Lockwood, Randall, and Frank R. Ascione. Cruelty to Animals and Interpersonal Violence: Readings in Research and Application. est Lafayette, Ind.: Purdue University Press, 1998.

Nagel, Thomas. Equality and Partiality. Oxford: Oxford University Press, 1991. - 'What Is It Like to Be a Bat?' The Philosophical Review 83, no. 4 (October 1, 1974): 435-450.

Nussbaum, Martha C. 'The Moral Status of Animals'. Chronicle of Higher Education 52, no. 22 (February 3, 2006): B6-8.

O’Neill, Onora. 'Kant on Duties Regarding Nonrational Nature'. Aristotelian Society Supplementary Volume 72, no. 1 (1998): 211-228.

Rawls, John. A Theory of Justice: Revised Edition. Cambridge, Massachusetts: Belknap Press of Harvard University Press, 1999.

Regan, Tom. Defending Animal Rights. Champaign, IL: University of Illinois Press, 2001.

The Case for Animal Rights. 2nd ed. Berkeley and Los Angeles: University of California Press, 2004.

Rowlands M. [1]. 'Contractarianism and Animal Rights'. Journal of Applied Philosophy 14 (November 1997): 235-247.

Saunders, Ben. 'Animals and World Ownership (unpublished)'. The University of Manchester, 2010.

Scanlon, Tom. What We Owe to Each Other. Cambridge, Massachusetts: The Belknap Press of Harvard University Press, 1998.

Sen, Amartya. Identity and Violence: The Illusion of Destiny. London: Penguin Books, 2007.

Simmons, Aaron. 'Animals, Predators, the Right to Life, and the Duty to Save Lives'. Ethics \& the Environment 14, no. 1 (2009): 15-27.

Singer, Peter. Animal Liberation: Towards an End to Man's Inhumanity to Animals. London: Granada Publishing, 1977.

Skidmore, James. 'Duties to Animals: The Failure of Kant's Moral Theory'. The Journal of Value Inquiry 35, no. 4 (December 1, 2001): 541-559.

Steven M. Wise, and Jane Goodall. Rattling the Cage: Toward Legal Rights for Animals. Cambridge, Massachusetts: Persius Publishing, 2000.

Thomas E. Hill. Respect, Pluralism, and Justice: Kantian Perspectives. Oxford University Press, USA, 2000.

Waldron, Jeremy. 'What Is Cosmopolitan?' Journal of Political Philosophy 8, no. 2 (June 1, 2000): 227-243. 
Wenz, Peter S. Environmental Justice. Albany: SUNY Press, 1988.

White, Thomas I. In Defense of Dolphins: The New Moral Frontier. Oxford: Wiley-Blackwell, 2007.

Wolf, Susan. 'Morality and Partiality'. Philosophical Perspectives 6 (1992): 243-259.

Wood, Allen W., and Onora O'Neill. 'Kant on Duties Regarding Nonrational Nature'. Proceedings of the Aristotelian Society, Supplementary Volumes 72 (January 1, 1998): 189-228. 